\title{
Austerity and fiscal prudence are health issues
}

\author{
Diane Kelsall MD MEd, Carsten Hennings MSc DBA
}

$\mathrm{T}$ he world has been transfixed by the latest installment in the Greek financial crisis. This summer, deadlines came and went, offers of debt relief were made and rejected, and a tentative agreement was finally reached between Greece and its creditors. However, the lengthy delay to an agreement came at a sizable cost — and not just a financial one. Greece is required to commit to austerity measures (policies intended to reduce the rapidly growing public sector debt) that are more drastic than may have been necessary earlier. Austerity measures affect all aspects of society, including health care, which can have serious effects on population health. Are we immune to such a scenario in Canada? Unfortunately, we are not.

To put it simply, the Greek financial crisis was a predictable result of a series of economic and political decisions. Although it did implement some austerity measures required for large bailouts in 2010 and 2012, the Greek government most recently failed to make the difficult - and unpopular political decisions needed to restructure the economy and satisfy its creditors. Even though the economy failed to grow as hoped, the government favoured spending over retrenchment, resulting in spiraling deficits. Postponing the day of reckoning only made things worse - an extra €30 billion was added to the bailout during July 2015 alone. As a result, the Greek people have suffered and will continue to do so for some time.

Budget constraints in times of economic crisis affect government priorities and spending in many areas, and may include disproportionate cuts to health care and a reliance on shifting costs to the consumer. ${ }^{1}$ Health effects can occur even among those with jobs, but the poor, less educated and unemployed are primarily affected. ${ }^{2}$

When austerity measures are implemented by governments, sometimes as a requirement by creditors, they may put even more strain on the health care system and, as a consequence, have greater effects on health. Greece, for example, has undergone $40 \%$ cuts to hospital budgets, closure of many health care facilities and shortages of staff and medical supplies, while user fees to access care have increased. ${ }^{3}$ Selfreported health has deteriorated; a rise in HIV infections (owing to reduced preventive services) and worsening mental health (suicides and major depressive disorders), particularly in people facing serious economic hardship, have been seen. Self-reported unmet medical need (the inability to obtain health care when one believes it to be necessary) has risen. ${ }^{3}$

As with health, prevention is better than attempting to "cure" an economy during a financial meltdown. It is difficult for countries to restructure their economic, health care and other systems during financial crises, although scarcity can clarify values and may resolve conflicts that hinder reform.
Worryingly, the Greek financial crisis shows that governments may postpone making the right choices, even when the need for action is clear and delay is likely to worsen the situation.

So, where do Canadians come into this picture? As consumers, we have largely chosen a "buy now, pay later" approach to our finances; we overvalue the present in our decision-making rather than take the effect of debt on our future seriously. Household debt is at a troubling high, with many Canadians neither saving nor paying off loans.

This attitude is mirrored politically, with multiple levels of government running problematic deficits. The governments we have elected have delayed making difficult fiscal decisions that involve serious discussions about priorities and tradeoffs - and we have let them do so. Collectively, we have been slow to demand measures to deal with growing public debt; indeed, we may have done the opposite at times. Those pushing for improvements in the health care system should not dismiss the importance of the economy or of fiscal responsibility.

There are multiple ways to be fiscally prudent, but these require difficult choices to be made by our governments around revenue, spending, investment and priorities in program delivery. Delaying these tough decisions, including those affecting the health care system, may be easier for politicians and for the rest of us now. However, postponing these decisions, especially when running problematic deficits, puts our governments at risk of having to make much more drastic choices in the future - at a time when the consequences may be far greater.

We may not be in the kind of trouble countries like Greece find themselves in today, but delays in making the right decisions, individually and collectively, will not serve us any better in the future than it has served them.

\section{References}

1. Cylus J, Mladovsky P, McKee M. Is there a statistical relationship between economic crises and changes in government health expenditure growth? An analysis of twenty-four European countries. Health Serv Res 2012;47:2204-24.

2. Zivin K, Paczkoski M, Galea S. Economic downturns and population mental health: research findings, gaps, challenges and priorities. Psychol Med 2011;41:1343-8.

3. Karanikolos M, Mladovsky P, Cylus J, et al. Financial crisis, austerity, and health in Europe. Lancet 2013;381:1323-31.

Competing interests: For Diane Kelsall's competing interests, see www .cmaj. ca/site/misc/cmaj_staff.xhtml. None declared for Carsten Hennings.

Affiliations: Deputy Editor (Kelsall), CMAJ; Chair, Department of Business Administration and Van Norman Chair of Business (Hennings), Tyndale University College, Toronto, Ont

Correspondence to: $C M A J$ editor, pubs@cmaj,ca

CMAJ 2015. DOI:10.1503/cmaj.150950 